\title{
Homeoprotein Neuroprotection of Embryonic Neuronal Cells
}

\author{
DiDtephanie E. Vargas Abonce, ${ }^{1 *}$ Mélanie Leboeuf, ${ }^{1,2 *}$ (1) Alain Prochiantz, ${ }^{1}$ and Kenneth L. Moya ${ }^{1}$
}

https://doi.org/10.1523/ENEURO.0061-19.2019

${ }^{1}$ Centre for Interdisciplinary Research in Biology (CIRB), Collège de France, CNRS UMR 7241/INSERM U1050, PSL Research University, Labex Memolife Paris Science et Lettres, 75005 Paris, France, and ${ }^{2}$ BrainEver, 75012 Paris, France

\begin{abstract}
Most homeoprotein transcription factors have a highly conserved internalization domain used in intercellular transfer. Internalization of homeoproteins ENGRAILED1 or ENGRAILED2 promotes the survival of adult dopaminergic cells, whereas that of OTX2 protects adult retinal ganglion cells. Here we characterize the in vitro neuroprotective activity of several homeoproteins in response to $\mathrm{H}_{2} \mathrm{O}_{2}$. Protection is observed with ENGRAILED1, ENGRAILED2, OTX2, GBX2, and LHX9 on midbrain and striatal embryonic neurons, whereas cell-permeable C-MYC shows no protective effects. Therefore, five homeoproteins belonging to three different classes (ANTENNAPEDIA, PAIRED, and LIM) share the ability to protect embryonic neurons from midbrain and striatum. Because midbrain and striatal neurons do not express the same repertoire of the four proteins, a lack of neuronal specificity together with a general protective activity can be proposed. Interestingly, hEN1 and GBX2 provided protection to primary midbrain astrocytes but not to non-neural cells, including mouse embryo fibroblasts, macrophages or HeLa cells. For the four proteins, protection against cell death correlated with a reduction in the number of $\mathrm{H}_{2} \mathrm{O}_{2}$-induced DNA break foci in midbrain and striatal neurons. In conclusion, within the limit of the number of cell types and homeoproteins tested, homeoprotein protection against oxidative stress-induced DNA breaks and death is specific to neurons and astrocytes but shows no homeoprotein or neuronal type specificity.
\end{abstract}

Key words: DNA damage; homeoprotein; neuroprotection; transcription factor

\section{Significance Statement}

Homeoproteins are DNA binding proteins regulating gene expression throughout life. Many of them transfer between cells and are thus internalized by live cells. This has allowed their use as therapeutic proteins in animal models of Parkinson's disease and glaucoma. Part of their therapeutic activity is through a protection against neuronal death. Here we show that internalized homeoproteins from three different classes protect embryonic ventral midbrain and striatal neurons from oxidative stress, at the level of both DNA damage and survival. The interest of this finding is that it lends weight to the possibility that many homeoproteins play a role in neuroprotection through shared mechanisms involving, in particular, DNA protection against stress-induced breaks.

\section{Introduction}

Homeoprotein (HP) transcription factors, discovered on the basis of their developmental functions, remain ex-

Received February 20, 2019; accepted August 14, 2019; First published August 26, 2019.

A.P and K.L.M. are listed on several patents for the use of homeoproteins for the treatment of neurodegenerative disease, and they are cofounders and hold pressed in the adult where they exert not fully understood physiologic activities (Di Nardo et al., 2018). Several HPs transfer between cells thanks to highly conserved secre-

shares in a company developing homeoproteins for therapeutic use. The authors declare no other competing financial interests.

A.P. and K.L.M. designed research; S.E.V.A. and M.L. performed research; S.E.V.A., M.L., and K.L.M. analyzed data; S.E.V.A., M.L., A.P., and K.L.M. wrote the paper. 
tion and internalization domains present in their DNA binding site or homeodomain (HD). HP internalization has allowed for the use of OTX2, ENGRAILED1 (EN1), and ENGRAILED2 (EN2; collectively ENGRAILED), as therapeutic proteins in animal models of Parkinson's disease (ENGRAILED) and glaucoma (OTX2; Sonnier et al., 2007; Alvarez-Fischer et al., 2011; Torero-lbad et al., 2011; Thomasson et al., 2019).

The two proteins EN1 and EN2 are expressed in adult midbrain dopaminergic (mDA) neurons (Di Nardo et al., 2007). These neurons degenerate progressively in parkinsonian patients, in classical Parkinson's disease animal models and in the En1-heterozygous mouse. In all models tested, ENGRAILED injected or infused is internalized by mDA neurons and prevents their death, even following a strong and acute oxidative stress provoked by a 6-hydroxydopamine hydrobromide (6-OHDA) injection at the level of the substantia nigra pars compacta (SNpc; Rekaik et al., 2015). The mechanisms involved in this protection have started to be analyzed. ENGRAILED internalization stimulates the translation of complex I mitochondrial proteins, restores the chromatin epigenetic marks disrupted by the stress, and allows for DNA repair, as quantified by the number of $\gamma \mathrm{H} 2 \mathrm{AX}$ foci (AlvarezFischer et al., 2011; Rekaik et al., 2015). In addition, ENGRAILED represses the expression of LINE-1 mobile elements caused by oxidative stress in vitro and in vivo (Blaudin de Thé et al., 2018). Because of the epigenetic nature of the protection mechanisms, a single injection of ENGRAILED has long-lasting effects, including in nonhuman primates (Thomasson et al., 2019), opening the way for a therapeutic use of this HP.

In view of developing ENGRAILED as a therapeutic protein, human EN1 (hEN1) was produced and purified; and an assay was adapted to test hEN1 for neuroprotection against oxidative stress and, in particular, to evaluate protein activity, specificity, and stability. Because OTX2 has a similar survival effect on mDA neurons and retinal ganglion cells (RGCs; Torero-lbad et al., 2011; Rekaik et al., 2015), it could be that protection against oxidative stress is a shared property of several HPs with little HP and/or neuronal specificity. To test this hypothesis, the protective effect of EN1, EN2, OTX2, GBX2, and LHX9 was evaluated on midbrain and striatal neurons in culture as well as testing hEN1 on a neuronal cell line. We show that the five proteins, but not cell-permeable c-MYC,

This research was supported by a MemoLife Labex PhD Fellowship to S.E.V.A., Association Nationale de la Recherche et de la Technologie Grant Cifre/ANRT 2017/ 0488 to M.L., BrainEver, and HomeoSign Grant ERC2013-AdG 339379.

${ }^{*}$ S.E.V.A. and M. L. contributed equally to this work.

Acknowledgments: We thank Marion Ruinart de Brimont, Yoko Arai, Bilal Mahzar, Raoul Torero-Ibad, Alain Joliot, Jessica Apulei, and Ariel A. Di Nardo for producing some of the proteins used.

Correspondence should be addressed to Alain Prochiantz at Alain. prochiantz@college-de-france.fr or Kenneth L. Moya at Ken.moya@ college-de-france.fr.

https://doi.org/10.1523/ENEURO.0061-19.2019

Copyright (C) 2019 Vargas Abonce et al.

This is an open-access article distributed under the terms of the Creative Commons Attribution 4.0 International license, which permits unrestricted use, distribution and reproduction in any medium provided that the original work is properly attributed. protect embryonic midbrain and striatal neurons against oxidative stress-induced cell death and DNA damage caused by $\mathrm{H}_{2} \mathrm{O}_{2}$ but are ineffective on mouse embryo fibroblasts (MEFs), peritoneal macrophages, and HeLa cells. hEN1 was also protective against $\mathrm{H}_{2} \mathrm{O}_{2}$ oxidative stress in primary midbrain astrocytes and against 6-OHDA in the dopaminergic LUHMES (Lund human mesencephalic) cells. The protective activity in the different cell types and against the two stressors involves reducing DNA damage.

\section{Materials and Methods}

\section{Animal treatment}

All animals were treated in accordance with the applicable guides, directives, and authorizations for the care and use of laboratory animals.

\section{Cell cultures}

For neuronal primary cultures, pregnant Swiss mice (Janvier) were killed by cervical dislocation $14.5 \mathrm{~d}$ postconception (dpc), and the embryos were extracted and placed in PBS-glucose $0.6 \%$. Striatal or midbrain structures were dissected in $2 \mathrm{ml}$ of PBS-glucose, and cells were mechanically dissociated and plated at a density of 25,000 cells/well in poly-L-ornithine $(15 \mu \mathrm{g} / \mathrm{ml}$ for glass coverslips and $1.5 \mu \mathrm{g} / \mathrm{ml}$ for plastic wells) and $2.5 \mu \mathrm{g} / \mathrm{ml}$ laminin-coated 96-well plates (Sigma-Aldrich) for LDH assay and 24-well plates with glass coverslips for immunocytochemistry. Cells were cultured in Life Technologies Neurobasal medium (Thermo Fisher Scientific) supplemented with glutamine (500 $\mu \mathrm{M}$; Sigma-Aldrich), glutamic acid (3.3 mg/L; Sigma-Aldrich), aspartic acid (3.7 mg/L; Sigma-Aldrich), Gibco Antibiotic-Antimycotic (anti-anti; Thermo Fisher Scientific), and Gibco B27 (Thermo Fisher Scientific; $\mathrm{NB}^{+}$) for $24 \mathrm{~h}$ at $37^{\circ} \mathrm{C}$ in a humidified incubator with $5 \% \mathrm{CO}_{2}$ atmosphere. All experiments were performed at $6 \mathrm{~d}$ in vitro (DIV).

Primary astrocytes were prepared from postnatal day 1 Swiss mice (Janvier) killed by decapitation. The midbrain was dissected, and the cells were mechanically dissociated. Cells were grown in $25 \mathrm{~cm}^{2}$ tissue culture flasks at $37^{\circ} \mathrm{C}$ with $5 \% \mathrm{CO}_{2}$ atmosphere in DMEM/F-12, Life Technologies GlutaMAX supplement (Thermo Fisher Scientific), supplemented with 10\% (v/v) Gibco fetal bovine serum (FBS; Thermo Fisher Scientific), high glucose, $5 \mathrm{~mm}$ Gibco HEPES (Thermo Fisher Scientific), and Gibco antianti (Thermo Fisher Scientific). Cells at $80 \%$ confluence were detached with $0.05 \%$ Gibco Trypsin-EDTA (Thermo Fisher Scientific), replated as above until reaching $80 \%$ confluence, trypsinized, seeded on 96-well plates at a density of 15,000 cells/well in the same culture medium, and cultured for $24 \mathrm{~h}$ before stopping proliferation with cytosine arabinoside ( $1 \mu \mathrm{M}$ Ara $\mathrm{C}$ ). This led to nearly pure astrocyte cultures, based on glial fibrillary acidic protein expression.

Primary MEFs were isolated from the skin of $11 \mathrm{dpc}$ Swiss mouse embryos (Janvier) according to Jozefczuk et al. (2012). Cells were grown on $75 \mathrm{~cm}^{2}$ tissue culture flask at $37^{\circ} \mathrm{C}$ in a humidified incubator with $5 \% \quad \mathrm{CO}_{2}$ atmosphere. Cells at $80 \%$ confluence were detached us- 
ing $0.05 \%$ Gibco Trypsin-EDTA (Thermo Fisher Scientific), plated at a density of 12,500 cells/well in 96-well tissue culture plastic plates and cultured for $24 \mathrm{~h}$ in DMEM, high glucose, and Gibco GlutaMAX (Thermo Fisher Scientific) supplemented with 10\% (v/v) Gibco FBS (Thermo Fisher Scientific) before the addition of $10 \mu \mathrm{M}$ Ara C.

HeLa cells (RRID:CVCL_0030) were maintained in DMEM, $1 \times$ g/L D-glucose L-glutamine, Gibco Pyruvate (Thermo Fisher Scientific) supplemented with $10 \%(\mathrm{v} / \mathrm{v})$ Gibco FBS (Thermo Fisher Scientific). Cells were grown on $75 \mathrm{~cm}^{2}$ tissue culture flasks at $37^{\circ} \mathrm{C}$ in a humidified incubator with $5 \% \mathrm{CO}_{2}$ atmosphere. Cells at $80 \%$ confluence were detached using $0.05 \%$ Gibco Trypsin-EDTA (Thermo Fisher Scientific) and plated at a density of 12,500 cells/well in 96-well tissue culture plastic plates. Cells were cultured for $24 \mathrm{~h}$ before stopping proliferation with $10 \mu \mathrm{M}$ Ara C.

Macrophages were isolated from the mouse peritoneal cavity of 8-week-old Swiss female mice (Janvier). Mice were killed by cervical dislocation and peritoneal washes were performed using HBSS. After massaging the peritoneum, the fluid containing resident macrophages was collected, seeded, and plated at a density of 100,000 cells/well in 96-well tissue culture plastic plates in Gibco DMEM + GlutaMAX (Thermo Fisher Scientific) and 2\% Gibco FBS (Thermo Fisher Scientific) at $37^{\circ} \mathrm{C}$ in a humidified incubator with $5 \% \mathrm{CO}_{2}$ atmosphere.

LUHMES cells (catalog \#CRL-2927, ATCC; RRID:CV$\mathrm{CL}$ B B056) were thawed rapidly at $37^{\circ} \mathrm{C}$, transferred to a $15 \mathrm{ml}$ Falcon tube with $3 \mathrm{ml}$ of AdvDMEM, and centrifuged for $7 \mathrm{~min}$ at $190 \times \mathrm{g}$. Supernatant was discarded, and $1 \mathrm{ml}$ of DMEM was added to the pellet. After gentle resuspension, the cells were placed in AdvDMEM+FGF $(40 \mathrm{ng} / \mathrm{ml})$ and cultured for $3 \mathrm{~d}$ at $37^{\circ} \mathrm{C}$ before trypsinization $(0.025 \%$ Trypsin $0.1 \mathrm{~g} / \mathrm{L}$ and EDTA in PBS) for $5 \mathrm{~min}$ at $37^{\circ} \mathrm{C}$, followed by the addition of $4 \mathrm{ml}$ of AdvDMEM medium and centrifugation for $7 \mathrm{~min}$ at $190 \times \mathrm{g}$. The cells were dissociated with $1 \mathrm{ml}$ of Advanced (Adv) DMEM+FGF and plated at a density of 30,000 cells/well on 96-well plates previously coated with laminin $(1 \mu \mathrm{g} / \mathrm{ml})$ and poly-Lornithine $(50 \mu \mathrm{g} / \mathrm{ml})$ for the LDH assay, or coated with laminin $(1 \mu \mathrm{g} / \mathrm{ml})$ and poly-L-ornithine $(500 \mu \mathrm{g} / \mathrm{ml})$ glass coverslips for immunocytochemistry. Cells were cultured in AdvDMEM+FGF for 1 or $3 \mathrm{~d}$ at $37^{\circ} \mathrm{C}$ in a humidified incubator with $5 \% \mathrm{CO}_{2}$ atmosphere for the $\mathrm{LDH}$ assay or $\gamma-\mathrm{H} 2 \mathrm{AX}$ foci analysis, respectively. Proteins ware added at the times indicated in the text in the presence $1 \mu \mathrm{m}$ Ara C.

\section{qRT-PCR}

Total RNA was extracted using the RNeasy Mini kit (Qiagen) and reverse transcribed using the QuantiTect Reverse Transcription kit (Qiagen). The qRT-PCR was made using SYBR-Green (Roche) and Light Cycler 480 (Roche). Data were analyzed using the "2-ddCt" method, and values were normalized to Gapdh (glyceraldehyde 3-phosphate dehydrogenase).

\section{Protein production}

Chicken ENGRAILED2 (chEN2) and mutant chicken ENGRAILED2 (SR-EN2), mouse EN1 (mEN1), hEN1, and mouse OTX2 (mOTX2) were prepared as described previously (Joliot et al., 1998; Torero-lbad et al., 2011). Cellpermeable recombinant human c-MYC was purchased from Abcam (catalog \#ab169901), and human GBX2 (hGBX2) and human LHX9 (hLHX9) were purchased from Proteogenix. Endotoxins were removed by phase separation according to Aida and Pabst (1990). Unless stated otherwise, proteins were stored at $-20^{\circ} \mathrm{C}$.

\section{Protein treatment and oxidative stress}

Cells were incubated with different concentrations of HPs diluted in culture media. For neutralization, HPs were preincubated with a 10-fold molar excess of antibody for $1 \mathrm{~h}$ at $37^{\circ} \mathrm{C}$. For $\mathrm{LDH}$ and trypan blue assay, oxidative stress was induced by incubation for $2 \mathrm{~h}$ at $37^{\circ} \mathrm{C}$ in $50 \mathrm{~mm}$ $\mathrm{H}_{2} \mathrm{O}_{2}$ (Sigma-Aldrich) or 6-OHDA $(300,200$, or $100 \mu \mathrm{M})$ diluted in culture media. For DNA break analysis, $\mathrm{H}_{2} \mathrm{O}_{2}$ $(100 \mu \mathrm{M})$ or $6-O H D A(10$ or $50 \mu \mathrm{M}$ ) were added for $1 \mathrm{~h}$. For dye-exclusion survival analysis, the media were replaced with $0.16 \%$ trypan blue for $5 \mathrm{~min}$ at room temperature (RT) then replaced with PBS, and the number of cells excluding trypan blue or not were counted blind in five fields of view at $20 \times$, five wells per condition. The LDH assay was conducted using the CytoTox 96 Non-Radioactive Cytotoxicity Assay (Promega) according to manufacturer instructions (Moravec, 1994).

\section{Immunocytochemistry}

Coverslips were washed three times in PBS, fixed in 4\% paraformaldehyde for 30 min at RT, washed in PBS three times, permeabilized with $\mathrm{PBS} / 0.5 \%$ Triton (SigmaAldrich) for $45 \mathrm{~min}$ at RT and placed in $100 \mathrm{~mm}$ Glycine for 30 min at RT. After a $1 \mathrm{~h}$ incubation at RT in PBS $/ 10 \%$ natural goat serum (NGS; Thermo Fisher Scientific)/1\% Triton, primary antibodies were added overnight at $4^{\circ} \mathrm{C}$. The next day coverslips were washed three times in PBS, incubated with secondary antibodies for $2 \mathrm{~h}$ at RT, washed three times in PBS, and mounted in DAPI Fluoromount-G (Southern Biotech). The mouse monoclonal anti- $\gamma \mathrm{H} 2 \mathrm{AX}$ antibody (IgG1) is from clone JBW301 (Millipore; RRID:AB_309864), the mouse monoclonal anti$\beta$-tubulin III (Tuj 1 IgG2A) from clone SDL.3D10 (SigmaAldrich; RRID:AB_532291). The two primary antibodies were used at a 1:500 dilution, and Alexa Fluor-conjugated goat anti-mouse (RRID:AB_2535764) and goat antichicken (RRID:AB_2535781) antibodies (Thermo Fisher Scientific) at a 1:2000 dilution.

\section{Quantification of DNA damage}

Images corresponding to a coverslip diameter were acquired with a Nikon i90 Microscope and exported to ImageJ. DNA damage was quantified by counting the number of $\gamma \mathrm{H} 2 \mathrm{AX}$ foci present in the nucleus of Tuj $1^{+}$ cells. Counting was conducted blind to conditions on four coverslips per condition.

\section{Statistical analysis}

Data are expressed as the mean \pm SD if not otherwise indicated, and results were analyzed with GraphPad Prism version 6 (RRID:SCR_002798). For the trypan blue experiment, statistical significance was determined by 
one-way ANOVA and two-tailed $t$ test using five wells per condition. For the LDH assay experiments, statistical significance was determined by one-way ANOVA and a post hoc Dunnett's test for comparisons to $\mathrm{H}_{2} \mathrm{O}_{2}$ using eight replicates per condition (ns: nonsignificant, $* p<0.5$, $* * p$ $<0.005$, $* * * p \leq 0.001$ and $* * * * p<0.001$ in all experiments). Statistical power (Table 1) for each significant difference was determined using the statistical power calculator (https://www.stat.ubc.ca/ rollin/stats/ssize/n2.html; accessed on 18-19 February 2019, 4 July and 24 July 2019, and 1 August 2019).

\section{Results}

\section{EN1 protects embryonic neurons against $\mathrm{H}_{2} \mathrm{O}_{2}$ oxidative stress}

Five independent hEN1 (human), one mEN1 (mouse), and one chEN2 (chicken) preparations produced similar results. Protective activity was measured by the LDH cytotoxicity assay, except for one experiment in which trypan blue exclusion was used for comparison. In the trypan blue experiment, mean survival of embryonic day 14.5 (E14.5) ventral midbrain cells in the control condition was $89.3 \pm 4.0 \%$. Two hours after adding $\mathrm{H}_{2} \mathrm{O}_{2}$, neuron survival was reduced to $36.5 \pm 14.1 \%(p<0.0001 \mathrm{com}-$ pared with control). The survival of neurons pretreated with $12.5 \mathrm{~nm}$ hEN1 was significantly greater (66.4 $\pm 9.6 \%$, $p<0.005)$ compared with $\mathrm{H}_{2} \mathrm{O}_{2}$-treated cells. The LDH assay gave qualitatively similar results and was thus used thereafter, making it easier to test different preparations and dose responses over a large range of HP concentrations.

$\mathrm{LDH}$ is a cytosolic enzyme and this assay measures $\mathrm{LDH}$ released into the culture medium after the lysis of live cells. Figure $1 A$ shows an hEN1 dose-response survival experiment for embryonic midbrain neurons at 6 DIV. Two hours after oxidative stress with $50 \mathrm{mM} \mathrm{H}_{2} \mathrm{O}_{2},>90 \%$ of the cells are dead. Pretreatment of the cells with $1.25 \mathrm{pM}$ to $12.5 \mathrm{~nm}$ significantly increases their survival from $\sim 28 \%$ to $86 \%$ in an EN1 dose-dependent manner. It is of note that $\mathrm{H}_{2} \mathrm{O}_{2}$ effects were variable between experiments with oxidative stress-induced cell death varying between $50 \%$ and $90 \%$. Based on this dose response, 12.5 and $2.5 \mathrm{nM} \mathrm{HP}$ concentrations allowing for total or near total protection were used in additional experiments.

Since hEN1 is a recombinant protein purified from bacterial extracts, its activity could be in part due to a contaminant. As shown in Figure $1 B$, protective activity was fully abolished by preincubation $\left(1 \mathrm{~h}\right.$ at $\left.37^{\circ} \mathrm{C}\right)$ of the protein with an anti-EN1 polyclonal antibody (AlvarezFischer et al., 2011), establishing that the neuroprotective activity is entirely due to hEN1. To examine hEN1 stability, aliquots were frozen on dry ice and thawed one or five times. Midbrain neurons were treated with $\mathrm{hEn} 1$, and $24 \mathrm{~h}$ later with $50 \mathrm{mM} \mathrm{H}_{2} \mathrm{O}_{2}$. Human EN1 frozen and thawed once provided $100 \%$ protection and $84-70 \%$ protection if frozen and thawed five times (Fig. $1 \mathrm{C}$, left). The protein maintained at $4^{\circ} \mathrm{C}$ for 6 weeks also retained full protective activity at 12.5 and $2.5 \mathrm{~nm}$ (Fig $1 C$, right).
Homeoprotein internalization is driven by the third helix of the homeodomain (Derossi et al., 1994) and within this sequence mutating tryptophan (W) in position 48 of the HD blocks internalization (Derossi et al., 1996). Accordingly, chEN2 internalization is abolished if the $W$ and phenylalanine $(F)$ residues at positions 48 and 49 of the HD are changed to serine and arginine (chEN2SR) residues, respectively (Joliot et al., 1998). Wild-type mEN1, hEN1, and chEN2 provided $100 \%$ protection against $\mathrm{H}_{2} \mathrm{O}_{2}$ oxidative stress while no protection was observed by chEN2SR (Fig. 1D), demonstrating that cell internalization is necessary for protection.

In addition to transcription, EN1 and EN2 also regulate protein translation (Brunet et al., 2005; Alvarez-Fischer et al., 2011; Stettler et al., 2012). Glutamate at position 50 of the homeodomain does not modify internalization but is necessary for high-affinity DNA binding and transcriptional activity (Le Roux et al., 1993). To determine whether ENGRAILED protective activity depended on transcription, hEN1 with a glutamine-to-alanine mutation at position 50 (hEN1Q50A) was produced. Figure $1 D$ illustrates that, in contrast with wild-type hEN1, incubation with hEN1Q50A at the same concentrations provided no protection against $\mathrm{H}_{2} \mathrm{O}_{2}$ oxidative stress. This demonstrates that EN1 protection against oxidative stress requires both internalization and high-affinity DNA binding activity.

\section{Other HPs protect primary neurons against oxidative stress}

Mouse EN1, hEN1, and mouse or chEN2 are neuroprotective toward midbrain dopaminergic cells in vitro and in vivo (Sonnier et al., 2007; Alvarez-Fischer et al., 2011; Rekaik et al., 2015). Protection was also observed for OTX2 on DA midbrain cells in vivo and on RGCs in vitro and in vivo (Sonnier et al., 2007; Alvarez-Fischer et al., 2011; Torero-lbad et al., 2011; Rekaik et al., 2015). This raised the possibility that protective activity may be a property shared among a number of HPs. To determine whether protection against oxidative stress is shared by several HPs from different classes, mOTX2, hLHX9, hGBX2, and chEN2 were compared with hEN1 in a single experiment with embryonic ventral midbrain neurons. Figure $2 A$ demonstrates that the four HPs provided significant protection against $50 \mathrm{~mm} \mathrm{H}_{2} \mathrm{O}_{2}$ at $12.5 \mathrm{~nm}$. Only hLHX9 at $2.5 \mathrm{~nm}$ failed to protect embryonic ventral midbrain neurons from $\mathrm{H}_{2} \mathrm{O}_{2}$ oxidative stress-induced cell death.

In contrast with the four HPs tested, a cell-permeable human MYC (hMYC) provided no protection (Fig. 2A). In addition, protection by all HPs, but not hMYC, was also observed with striatal embryonic neurons (Fig. 2B). This suggests that protection against oxidative stress may be specific to HPs with little neuronal subtype specificity. The fact that both striatal and midbrain neurons were protected, and the absence of HP specificity led us to use hEN1 and hGBX2 to verify whether they protected nonneuronal cells, including primary astrocytes, primary MEFs, HeLa cells, and primary mouse macrophages. One hundred $\mathrm{mM} \mathrm{H}_{2} \mathrm{O}_{2}$ killed $\sim 50 \%$ of primary astrocytes, while $12.5 \mathrm{~nm}$ hEN1 or hGBX2 completely protected 
Table 1. Statistical power analysis

\begin{tabular}{|c|c|c|c|}
\hline \multicolumn{2}{|c|}{ Data structure } & \multirow{2}{*}{$\begin{array}{c}\text { Type of test } \\
\text { Post hoc } t \text { test, two-tailed }\end{array}$} & \multirow{2}{*}{$\begin{array}{l}\text { Power } \\
1.00\end{array}$} \\
\hline Trypan blue & Control vs $\mathrm{H}_{2} \mathrm{O}_{2}$ & & \\
\hline & $\mathrm{H}_{2} \mathrm{O}_{2}$ vs $12.5 \mathrm{~nm}$ & & 0.92 \\
\hline \multirow[t]{6}{*}{ Figure $1 A$} & $\mathrm{H}_{2} \mathrm{O}_{2}$ vs $12.5 \mathrm{~nm}$ & Dunnett's multiple comparisons & 1.000 \\
\hline & $\mathrm{H}_{2} \mathrm{O}_{2}$ vs $2.5 \mathrm{~nm}$ & & 1.000 \\
\hline & $\mathrm{H}_{2} \mathrm{O}_{2}$ vs $25 \mathrm{pm}$ & & 1.000 \\
\hline & $\mathrm{H}_{2} \mathrm{O}_{2}$ vs $12.5 \mathrm{pm}$ & & 1.00 \\
\hline & $\mathrm{H}_{2} \mathrm{O}_{2}$ vs $2.5 \mathrm{pm}$ & & 1.000 \\
\hline & $\mathrm{H}_{2} \mathrm{O}_{2}$ vs $1.25 \mathrm{~nm}$ & & 1.000 \\
\hline \multirow[t]{2}{*}{ Figure $1 B$} & $\mathrm{H}_{2} \mathrm{O}_{2}$ vs $12.5 \mathrm{~nm}$ & Dunnett's multiple comparisons & 1.000 \\
\hline & $\mathrm{H}_{2} \mathrm{O}_{2}$ vs $2.5 \mathrm{nM}$ & & 1.00 \\
\hline \multirow[t]{6}{*}{ Figure $1 C$} & $\mathrm{H}_{2} \mathrm{O}_{2}$ vs $12.5 \mathrm{~nm} 1 \times$ frozen & Dunnett's multiple comparisons & 1.000 \\
\hline & $\mathrm{H}_{2} \mathrm{O}_{2}$ vs $2.5 \mathrm{~nm} 1 \times$ frozen & & 1.00 \\
\hline & $\mathrm{H}_{2} \mathrm{O}_{2}$ vs $12.5 \mathrm{~nm} 5 \times$ frozen & & 1.00 \\
\hline & $\mathrm{H}_{2} \mathrm{O}_{2}$ vs $2.5 \mathrm{~nm} 5 \times$ frozen & & 1.000 \\
\hline & $\mathrm{H}_{2} \mathrm{O}_{2}$ vs $12.5 \mathrm{~nm} 4^{\circ} \mathrm{C}$ & & 1.000 \\
\hline & $\mathrm{H}_{2} \mathrm{O}_{2}$ vs $2.5 \mathrm{~nm} 4^{\circ} \mathrm{C}$ & & 1.000 \\
\hline \multirow[t]{6}{*}{ Figure $1 D$} & $\mathrm{H}_{2} \mathrm{O}_{2}$ vs $12.5 \mathrm{~nm}$ chEn2 & Dunnett's multiple comparisons & 1.000 \\
\hline & $\mathrm{H}_{2} \mathrm{O}_{2}$ vs $2.5 \mathrm{~nm}$ chEn2 & & 1.000 \\
\hline & $\mathrm{H}_{2} \mathrm{O}_{2}$ vs $12.5 \mathrm{~nm}$ hEn1Q50A & & 1.000 \\
\hline & $\mathrm{H}_{2} \mathrm{O}_{2}$ vs $2.5 \mathrm{~nm}$ hEn1Q50A & & 1.000 \\
\hline & $\mathrm{H}_{2} \mathrm{O}_{2}$ vs $12.5 \mathrm{~nm} h E n 2$ & & 1.000 \\
\hline & $\mathrm{H}_{2} \mathrm{O}_{2}$ vs $2.5 \mathrm{~nm}$ hEn2 & & 1.000 \\
\hline \multirow[t]{7}{*}{ Figure $2 A$} & $\mathrm{H}_{2} \mathrm{O}_{2}$ vs $12.5 \mathrm{~nm}$ hEn1 & Dunnett's multiple comparisons & 1.000 \\
\hline & $\mathrm{H}_{2} \mathrm{O}_{2}$ vs $2.5 \mathrm{~nm}$ hEn1 & & 1.000 \\
\hline & $\mathrm{H}_{2} \mathrm{O}_{2}$ vs $12.5 \mathrm{~nm}$ mOtx2 & & 1.000 \\
\hline & $\mathrm{H}_{2} \mathrm{O}_{2}$ vs $2.5 \mathrm{~nm}$ mOtx2 & & 1.000 \\
\hline & $\mathrm{H}_{2} \mathrm{O}_{2}$ vs $12.5 \mathrm{~nm}$ hGbx2 & & 1.000 \\
\hline & $\mathrm{H}_{2} \mathrm{O}_{2}$ vs $2.5 \mathrm{~nm}$ hGbx2 & & 1.000 \\
\hline & $\mathrm{H}_{2} \mathrm{O}_{2}$ vs $12.5 \mathrm{~nm}$ hLhx9 & & 1.000 \\
\hline \multirow[t]{8}{*}{ Figure $2 B$} & $\mathrm{H}_{2} \mathrm{O}_{2}$ vs $12.5 \mathrm{~nm} \mathrm{hEn} 1$ & Dunnett's multiple comparisons & 1.000 \\
\hline & $\mathrm{H}_{2} \mathrm{O}_{2}$ vs $2.5 \mathrm{~nm} \mathrm{hEn} 1$ & & 1.000 \\
\hline & $\mathrm{H}_{2} \mathrm{O}_{2}$ vs $12.5 \mathrm{~nm}$ mOtx2 & & 1.000 \\
\hline & $\mathrm{H}_{2} \mathrm{O}_{2}$ vs $2.5 \mathrm{~nm}$ mOtx2 & & 1.000 \\
\hline & $\mathrm{H}_{2} \mathrm{O}_{2}$ vs $12.5 \mathrm{~nm}$ hGbx2 & & 1.000 \\
\hline & $\mathrm{H}_{2} \mathrm{O}_{2}$ vs $2.5 \mathrm{~nm}$ hGbx2 & & 1.000 \\
\hline & $\mathrm{H}_{2} \mathrm{O}_{2}$ vs $12.5 \mathrm{~nm}$ hLhx9 & & 1.000 \\
\hline & $\mathrm{H}_{2} \mathrm{O}_{2}$ vs $2.5 \mathrm{~nm}$ hLhx9 & & 1.000 \\
\hline \multirow[t]{4}{*}{ Figure $2 C$} & $\mathrm{H}_{2} \mathrm{O}_{2}$ vs $12.5 \mathrm{~nm}$ hEn1 & Dunnett's multiple & 1.000 \\
\hline & $\mathrm{H}_{2} \mathrm{O}_{2}$ vs $2.5 \mathrm{~nm}$ hEn1 & comparisons & 1.000 \\
\hline & $\mathrm{H}_{2} \mathrm{O}_{2}$ vs $12.5 \mathrm{~nm}$ hGbx2 & & 1.000 \\
\hline & $\mathrm{H}_{2} \mathrm{O}_{2}$ vs $12.5 \mathrm{~nm}$ hLhx9 & & 1.00 \\
\hline \multirow[t]{16}{*}{ Figure $3 B$} & $\mathrm{H}_{2} \mathrm{O}_{2}$ vs $2.5 \mathrm{~nm}$ mEn1 & Dunnett's multiple comparisons & 1.00 \\
\hline & $\mathrm{H}_{2} \mathrm{O}_{2}$ vs $1.25 \mathrm{~nm}$ mEn1 & & 1.000 \\
\hline & $\mathrm{H}_{2} \mathrm{O}_{2}$ vs 0.62 nм mEn1 & & 1.00 \\
\hline & $\mathrm{H}_{2} \mathrm{O}_{2}$ vs $0.31 \mathrm{~nm} \mathrm{mEn} 1$ & & 1.00 \\
\hline & $\mathrm{H}_{2} \mathrm{O}_{2}$ vs $3.3 \mathrm{~nm}$ mOtx2 & & 1.000 \\
\hline & $\mathrm{H}_{2} \mathrm{O}_{2}$ vs $1.65 \mathrm{~nm}$ mOtx2 & & 1.00 \\
\hline & $\mathrm{H}_{2} \mathrm{O}_{2}$ vs $0.82 \mathrm{~nm}$ mOtx2 & & 1.000 \\
\hline & $\mathrm{H}_{2} \mathrm{O}_{2}$ vs $0.41 \mathrm{~nm}$ mOtx2 & & 1.00 \\
\hline & $\mathrm{H}_{2} \mathrm{O}_{2}$ vs $2.68 \mathrm{~nm}$ hGbx2 & & 1.000 \\
\hline & $\mathrm{H}_{2} \mathrm{O}_{2}$ vs 1.34 nM hGbx2 & & 1.000 \\
\hline & $\mathrm{H}_{2} \mathrm{O}_{2}$ vs $0.67 \mathrm{~nm} h \mathrm{Gbx} 2$ & & 1.000 \\
\hline & $\mathrm{H}_{2} \mathrm{O}_{2}$ vs $0.33 \mathrm{~nm} h \mathrm{Gbx} 2$ & & 1.000 \\
\hline & $\mathrm{H}_{2} \mathrm{O}_{2}$ vs $2.27 \mathrm{~nm} h L h \times 9$ & & 1.000 \\
\hline & $\mathrm{H}_{2} \mathrm{O}_{2}$ vs $1.14 \mathrm{~nm}$ hLhx9 & & 1.000 \\
\hline & $\mathrm{H}_{2} \mathrm{O}_{2}$ vs $0.56 \mathrm{~nm} \mathrm{hLhx9}$ & & 1.000 \\
\hline & $\mathrm{H}_{2} \mathrm{O}_{2}$ vs $0.28 \mathrm{~nm}$ hLhx9 & & 1.000 \\
\hline \multirow[t]{2}{*}{ Figure $3 C$} & $\mathrm{H}_{2} \mathrm{O}_{2}$ vs stavudine & Dunnett's multiple comparisons & 1.000 \\
\hline & $\mathrm{H}_{2} \mathrm{O}_{2}$ vs hEn1 & & 1.000 \\
\hline \multirow[t]{2}{*}{ Figure $3 D$} & $\mathrm{H}_{2} \mathrm{O}_{2}$ vs stavudine & Dunnett's multiple comparisons & 1.000 \\
\hline & $\mathrm{H}_{2} \mathrm{O}_{2}$ vs hEn1 & & 1.000 \\
\hline \multirow[t]{2}{*}{ Figure $4 A$} & $-\mathrm{hEN} 1 \mathrm{vs}+\mathrm{hEN} 1$ at $300 \mu \mathrm{M}$ 6-OHDA & Post hoc $t$ test, two-tailed & 1.000 \\
\hline & -hEN1 vs +hEN1 at $200 \mu \mathrm{M}$ 6-OHDA & Post hoc $t$ test, two-tailed & 1.000 \\
\hline Figure $4 B$ & $-\mathrm{hEN} 1 \mathrm{vs}+\mathrm{hEN} 1$ at $10 \mu \mathrm{M}$ 6-OHDA & Post hoc $t$ test, two-tailed & 1.000 \\
\hline & $-\mathrm{hEN} 1 \mathrm{vs}+\mathrm{hEN} 1$ at $50 \mu \mathrm{M}$ 6-OHDA & Post hoc $t$ test, two-tailed & 1.000 \\
\hline
\end{tabular}

against this oxidative stress (Fig. 2C). Figure 2 also illustrates that although MEFs (Fig. 2D) and HeLa cells (Fig. $2 E$ ) are more resistant to $\mathrm{H}_{2} \mathrm{O}_{2}$-induced oxidative stress than neurons (Fig. $2 A, B$ ) or macrophages (Fig. 2F), none of the non-neural cells are protected by the two tested HPs or by cell-permeable c-MYC. 
A

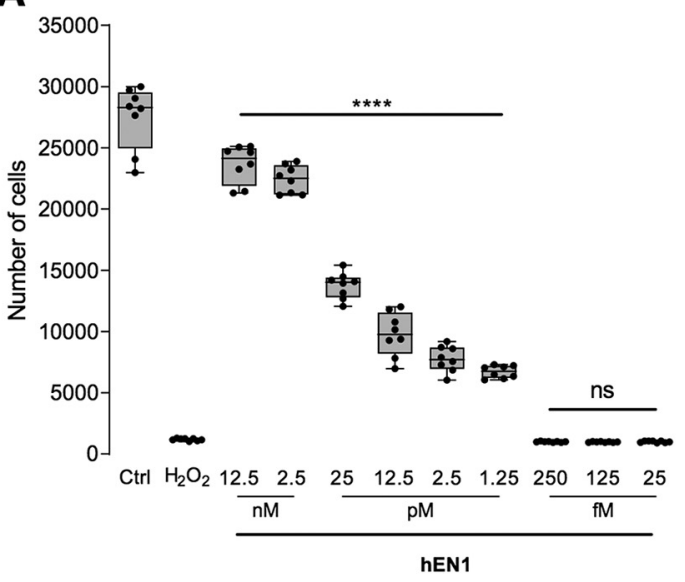

C
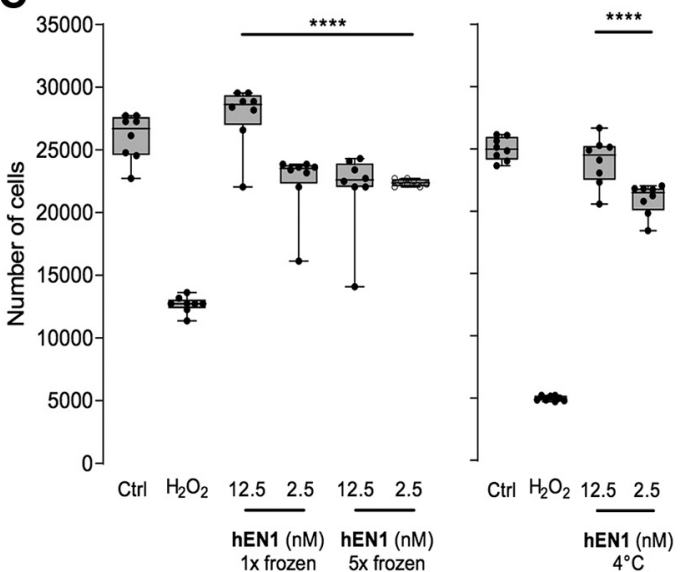

B

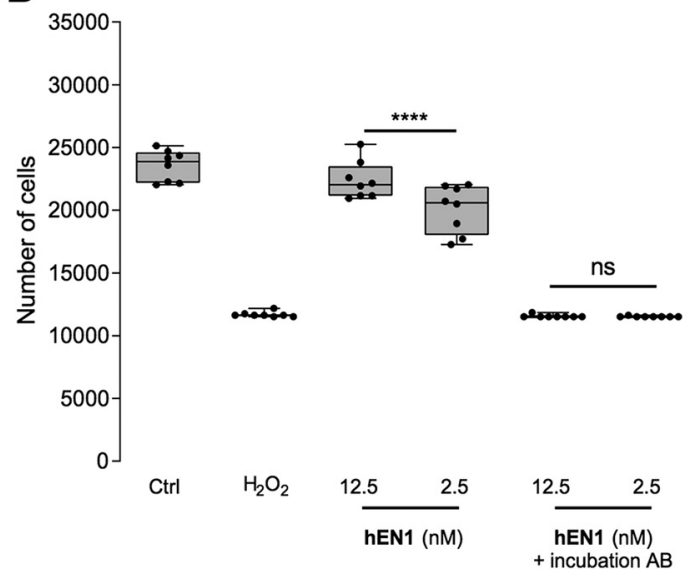

D

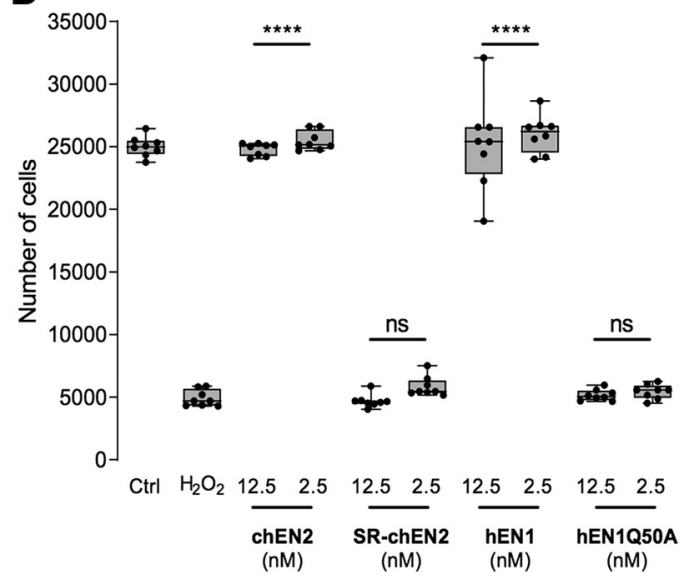

Figure 1. ENGRAILED protection of embryonic midbrain neurons. $\boldsymbol{A}$, hEN1 dose-dependent survival of embryonic neurons after $\mathrm{H}_{2} \mathrm{O}_{2}$ oxidative stress. $\boldsymbol{B}$, Preadsorption of hEN1 with an anti-ENGRAILED antibody abrogates hEN1 neuroprotection. $\boldsymbol{C}$, hEN1 subjected to repeated freeze-thaw cycles (left) or maintained at $4^{\circ} \mathrm{C}$ for 6 weeks (right) has significant neuroprotective activity against oxidative stress. $\boldsymbol{D}$, ENGRAILED internalization and high-affinity DNA binding are necessary for ENGRAILED neuroprotection. LDH assay was used for $\boldsymbol{A}-\boldsymbol{D}$. ns, nonsignificant, $* * * * p<0.0001$.

To verify whether this large HP spectrum was related to unspecific HP expression in culture conditions, we compared the expression of GBX2, LHX9, OTX2, and EN1 in 6 DIV cultures and adult tissues using qRT-PCR. Figure 2G illustrates that MEFs in culture express none of the HPs, and that, in the embryonic cultures, GBX2 is expressed in striatal neurons only, LHX9 and OTX2 in midbrain and striatal neurons and EN1 in midbrain neurons only. For comparison, OTX2 is expressed in adult midbrain and striatum, and EN1 is expressed in adult midbrain, whereas LHX9 and GBX2 are barely expressed in the two structures (Fig. 2F). These data demonstrate that a given HP can protect neurons that do not normally express it. For example, striatal neurons are protected from oxidative stress by EN1, yet they do not express it. Similarly, midbrain neurons are protected by GBX2, which they do not express.

\section{Homeoproteins protect midbrain embryonic neurons against DNA damage}

Oxidative stress causes a number of changes in cell physiology, among which is the production of DNA breaks. In studies of neuroprotection of ventral midbrain neurons in vivo, Rekaik et al. (2015) observed that ENGRAILED reduces the number of anti- $\gamma \mathrm{H} 2 \mathrm{AX}$-stained DNA damage foci induced in the nuclei of mDA cells exposed to 6-OHDA. To examine whether this is also the case in the present in vitro conditions and for the four HPs studied, embryonic midbrain neurons were cultured for 6 DIV, treated with the mEN1 at a $2.5 \mathrm{nM}$ concentration for $24 \mathrm{~h}$, and exposed for $1 \mathrm{~h}$ to $100 \mu \mathrm{M} \mathrm{H}_{2} \mathrm{O}_{2}$. The cells were fixed, and $\gamma \mathrm{H} 2 \mathrm{AX}$ foci were revealed by immunocytochemistry in neurons identified by $\beta$ III tubulin labeling. Without $\mathrm{H}_{2} \mathrm{O}_{2}$, neurons had only one or two $\gamma \mathrm{H} 2 \mathrm{AX}$ foci while $\mathrm{H}_{2} \mathrm{O}_{2}$ increased the number of foci about fourfold. Pretreatment with mEN1 reduced the number of $\gamma \mathrm{H} 2 \mathrm{AX}$ foci as illustrated in Figure $3 A$. As quantified in Figure $3 B$, the reduction in $\gamma \mathrm{H} 2 \mathrm{AX}$ foci was dose dependent for mEN1, hLHX9, hGBX2, and mOTX2 at concentrations ranging from 2.3/3.3 to $0.3 / 0.4 \mathrm{nM}$ depending on the HP. Thus, each of the HPs tested protects neurons from oxidative stress, promotes their survival and reduces the level of DNA damage caused by $\mathrm{H}_{2} \mathrm{O}_{2}$. 
A

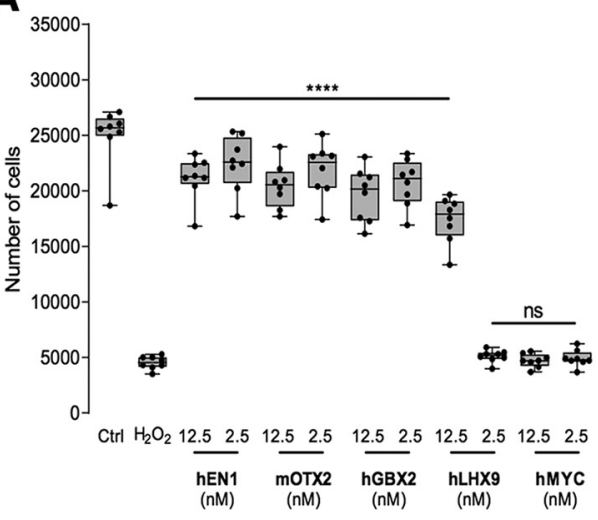

C

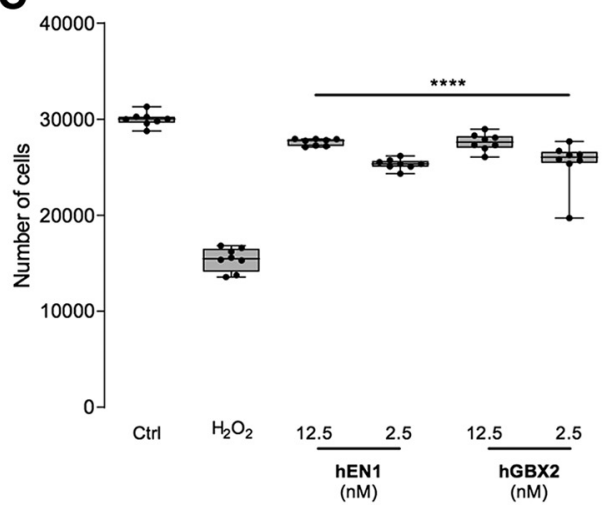

E

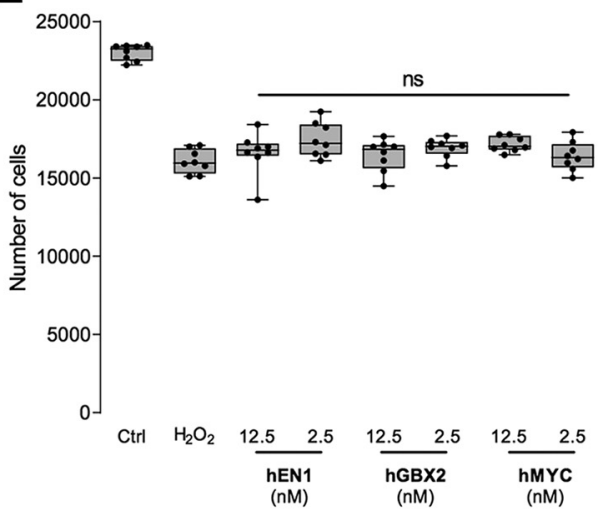

B

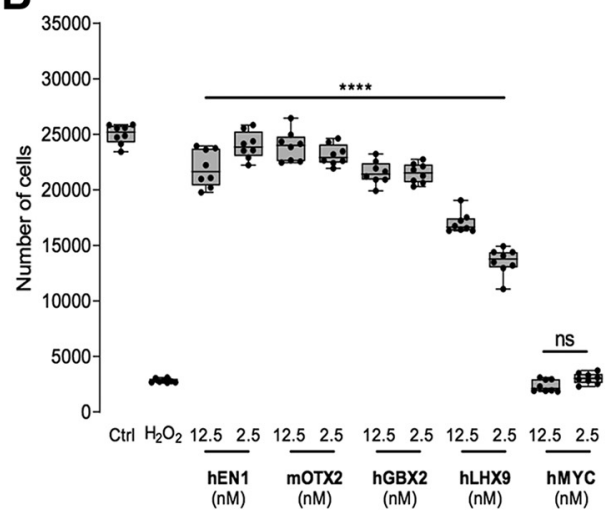

D

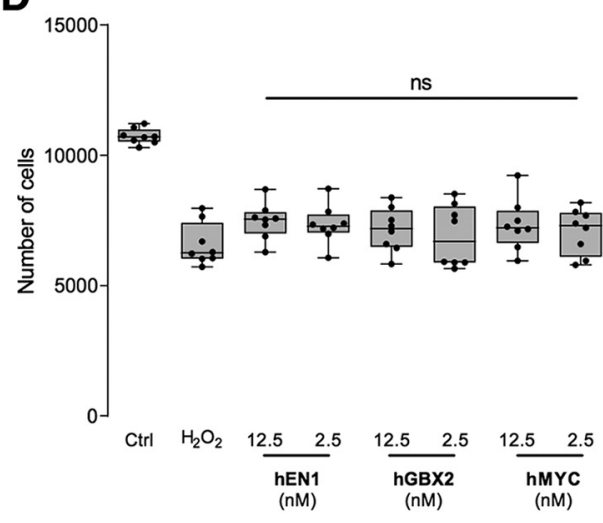

F

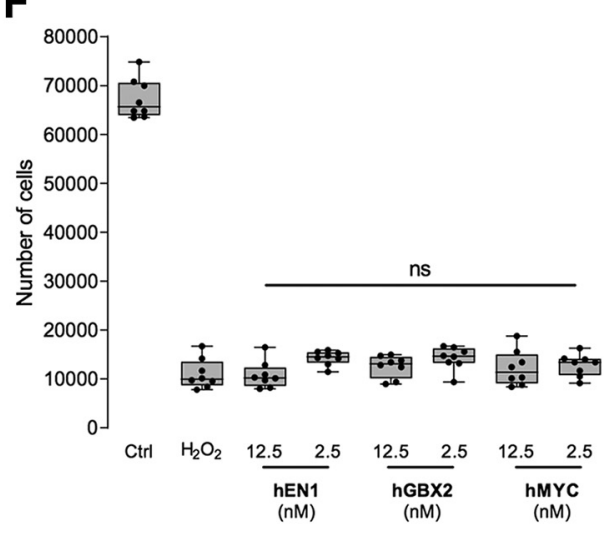

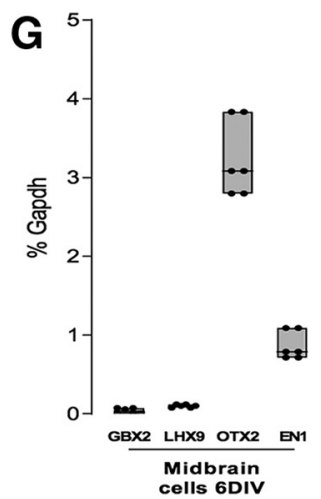
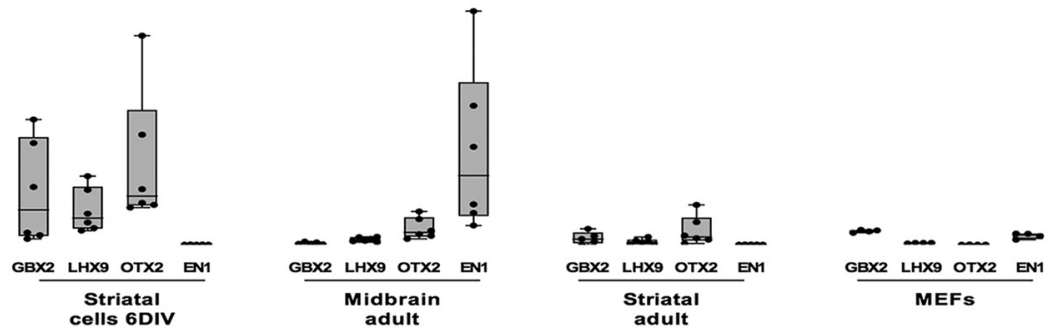

Figure 2. Homeoproteins protect embryonic neurons but not non-neuronal cells in the LDH assay. A, hEN1, mOTX2, GBX2, and 
continued

hLHX9 protect embryonic ventral midbrain cells against $\mathrm{H}_{2} \mathrm{O}_{2}$ oxidative stress, while hMYC does not. $\boldsymbol{B}$, hEN1, mOTX2, GBX2, and hLHX9 protect embryonic striatal neurons against $\mathrm{H}_{2} \mathrm{O}_{2}$ oxidative stress, while hMYC does not. $\boldsymbol{C}$, hE1 and hGBX2 protect primary astrocytes against $\mathrm{H}_{2} \mathrm{O}_{2}$ oxidative stress. $\boldsymbol{D}$, hEN1, hGBX2, and hMYC do not protect fibroblasts against $\mathrm{H}_{2} \mathrm{O}_{2}$ oxidative stress. $\boldsymbol{E}$, hEN1, hGBX2, and hMYC do not protect HeLa cells against $\mathrm{H}_{2} \mathrm{O}_{2}$ oxidative stress. $\boldsymbol{F}$, hEN1, hGBX2, and hMYC do not protect macrophages against $\mathrm{H}_{2} \mathrm{O}_{2}$ oxidative stress. G, qRT-PCR reveals the expression of GBX2, LHX9, and OTX2 in embryonic striatum, and $L H X 9, O T X 2$, and EN1 in ventral midbrain. ns, nonsignificant, $* * * * p<0.0001$.

Mobile element LINE-1 (L1) expression by midbrain neurons is increased by oxidative stress in vitro and in vivo and the endonuclease encoded by L1 ORFp2 (open reading frame 2 ) is in part responsible for the breaks (Blaudin de Thé et al., 2018). Accordingly, the protective activity of hEN1 is due to its ability to repress oxidative stress-induced LINE-1 overexpression (Blaudin de Thé et al., 2018). Here, EN1 and the reverse transcriptase inhibitor stavudine used as a LINE-1 antagonist protected the oxidative stress-induced formation of DNA brakes in midbrain neurons. This led us to compare the effects of an overnight pretreatment by $12.5 \mathrm{nM}$ EN1 or $10 \mu \mathrm{M}$ and stavudine on the number of $\gamma \mathrm{H} 2 \mathrm{AX}$ foci in midbrain (Fig. $3 C$ ) and striatal cell cultures (Fig. 3D) following a $1 \mathrm{~h}$ incubation with $100 \mu \mathrm{M} \mathrm{H}_{2} \mathrm{O}_{2}$. Figure 3, $\mathrm{C}$ and $D$, illustrates that $100 \mu \mathrm{M} \mathrm{H}_{2} \mathrm{O}_{2}$ increased the number of $\gamma$ - $\mathrm{H} 2 \mathrm{AX}$ foci by about twofold in embryonic striatal and midbrain neurons compared with control and that stavudine at $10 \mu \mathrm{M}$ significantly reduced the foci to the same extent as hEN1 at $12.5 \mathrm{~nm}$.

\section{hEN1 protects a dopaminergic cell line against 6- OHDA toxicity}

ENGRAILED and OTX2 protect mesencephalic dopaminergic neurons in vivo against an oxidative stress induced by 6-OHDA (Rekaik et al., 2015). To verify whether this is also the case in vitro and to follow the DNA protection activity, we used immortalized human dopaminergic neuronal precursors, LUHMES cells, that express the DA transporter and are thus sensitive to 6-OHDA (as opposed to midbrain neurons in which the mDA neurons constitute a minority of the cell population). Figure 4 demonstrates that LUHMES cells are sensitive to the toxin at 200 and $300 \mu \mathrm{M}$ concentrations and entirely protected by a preincubation with $50 \mathrm{~nm}$ hEN1. DNA breaks were also followed at lower 6-OHDA concentrations, which induce breaks without provoking rapid cell death. As shown in Figure $4 B$, hEN1 reduces the number of breaks, confirming its protective activity in the 6-OHDA oxidative stress paradigm.

\section{Discussion}

Exogenous ENGRAILED protects DA neurons in vitro against $\mathrm{MPP}^{+}$and rotenone, and in vivo against 6-OHDA, MPTP, A30P $\alpha$-synuclein, and progressive degeneration associated with the loss of one En1 allele (Sonnier et al., 2007; Alvarez-Fischer et al., 2011; Rekaik et al., 2015; Thomasson et al., 2019). OTX2 promotes the survival of adult dissociated RGCs in vitro, protects RGCs in vivo against NMDA excitotoxicity and mDA neurons against 6-OHDA (Torero-lbad et al., 2011; Rekaik et al., 2015). This similar prosurvival activity of two distinct transcrip- tion factors of different HP families led us to develop an in vitro assay to assess the ability of several HPs belonging to different classes to protect embryonic neurons against cell death and DNA damage caused by $\mathrm{H}_{2} \mathrm{O}_{2}$ oxidative stress. EN1, EN2, and GBX2 are members of the ANTENNAPEDIA class, OTX2 belongs to the PAIRED class, and LHX9 is part of the LIM class of HPs (Boncinelli, 1997).

The present results show that ENGRAILED internalization and high-affinity DNA binding properties are necessary for its neuroprotective activity. This is in accord with previous results showing that when the WF at positions 85 and 86 in OTX2 (thus, in positions 48 and 49 of its homeodomain) are mutated to YL, OTX2 loses its ability to be internalized and its neuroprotective activity for RGCs in vitro and in vivo (Torero-lbad et al., 2011). The requirement for high-affinity DNA binding suggests that survival activity implies transcriptional regulation and not signal transduction through a cell surface receptor. This does not preclude activity at several other levels, including the regulation of protein synthesis or the maintenance of a healthy heterochromatin, as demonstrated in studies on the protection of SNpc mDA neurons by ENGRAILED (Alvarez-Fischer et al., 2011; Stettler et al., 2012; Rekaik et al., 2015; Thomasson et al., 2019). Whether these conclusions apply to all other HPs tested here is an open question.

DNA break-induced signaling such as the phosphorylation of the histone variant $\mathrm{H} 2 \mathrm{AX}(\gamma \mathrm{H} 2 \mathrm{AX})$ is required for transcriptional elongation in healthy cells. In this case, $\gamma \mathrm{H} 2 \mathrm{AX}$ accumulates at gene transcription start sites (TSSs) during Pol II pause release (Bunch et al., 2015). However, there are clear differences between the latter situation and $\gamma \mathrm{H} 2 \mathrm{AX}$-marked double-strand breaks (DSBs) induced by damaging conditions, including oxidative stress. In TSSs, $\gamma \mathrm{H} 2 \mathrm{AX}$ accumulation is condensed within the transcribed units only, and there is no spread outside the boundaries of the transcribed genes. In contrast, $\gamma \mathrm{H} 2 \mathrm{AX}$ accumulation due to DNA damage can spread over megabases in both directions from DSB sites. Here, the oxidative agents $\mathrm{H}_{2} \mathrm{O}_{2}$ and 6-OHDA significantly increased the number of $\gamma \mathrm{H} 2 \mathrm{AX}$ foci in embryonic neurons or LUHMES cells, respectively. Pretreatment with EN1, OTX2, GBX2, or LHX9 (embryonic neurons) or EN1 (LUHMES cells) prevented the formation of DSBs. Interestingly, another homeobox gene, HOXB7, enhances nonhomologous end-joining DNA repair in vitro and in vivo (Rubin et al., 2007), providing additional support for the involvement of homeoproteins in DNA break repair.

Homeoproteins of different species (chicken, mouse, and human) protect mouse embryonic neurons against oxidative stress, suggesting an evolutionary conservation 


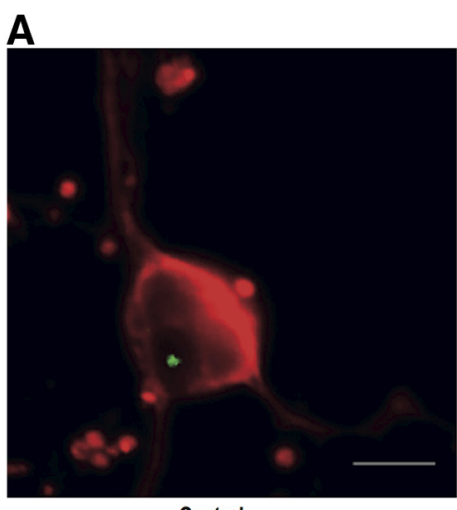

Control

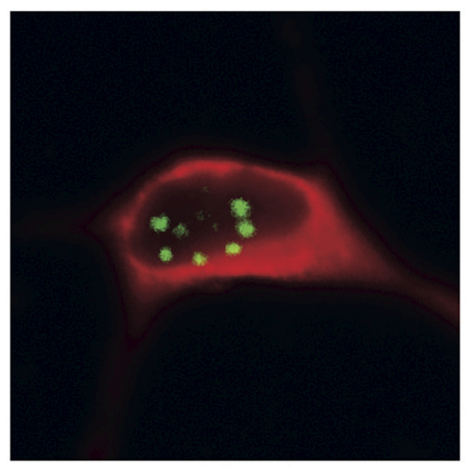

$\mathrm{H}_{2} \mathrm{O}_{2}(100 \mu \mathrm{M})$

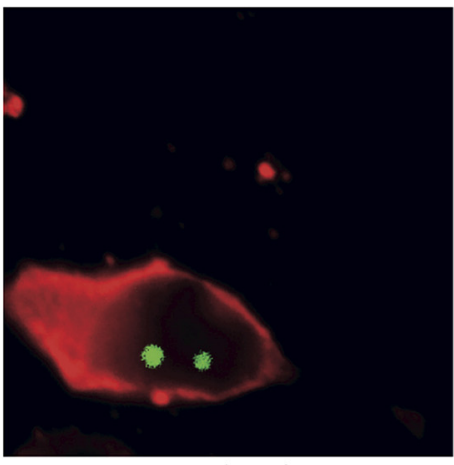

mEN1 (2.5 nM)

B
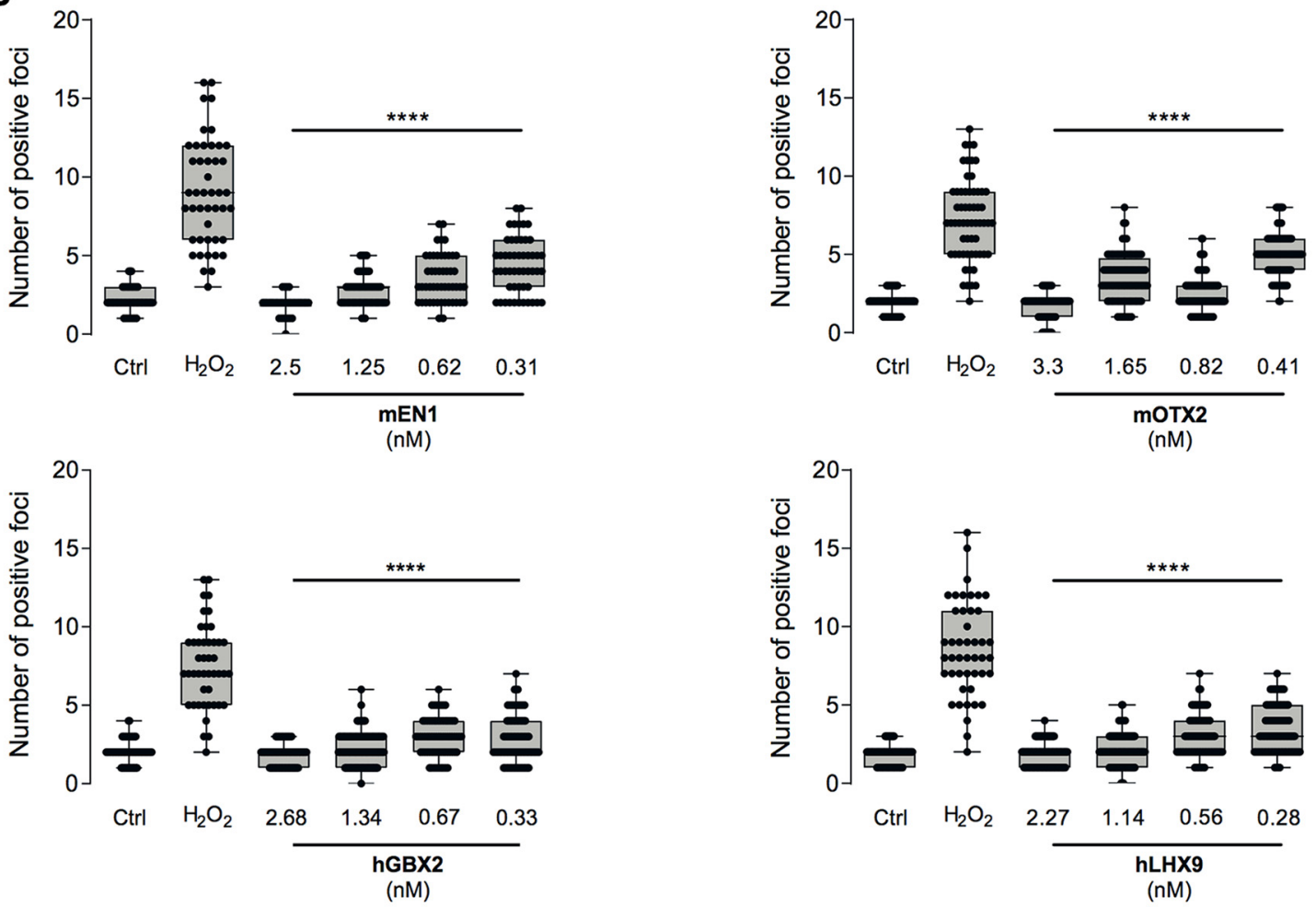

C

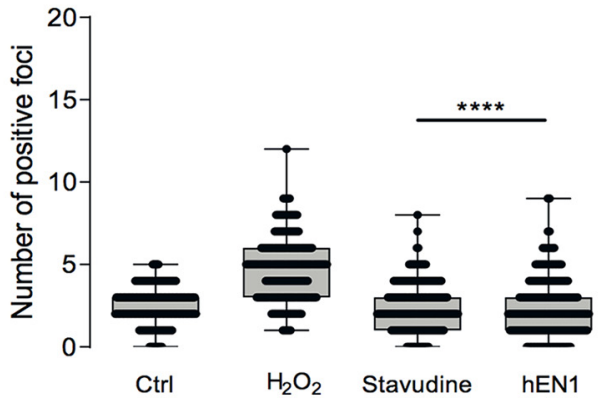

D

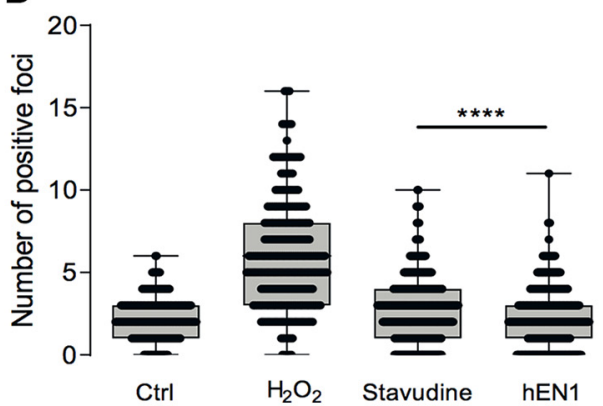

Figure 3. HPs reduce DNA breaks after $\mathrm{H}_{2} \mathrm{O}_{2}$. A . Cultures of $\mathrm{E} 14.5$ ventral midbrain neurons (red) untreated (control) show few bright $\gamma \mathrm{H} 2 \mathrm{AX}$ foci (green), while those treated with $100 \mu \mathrm{m} \mathrm{H}_{2} \mathrm{O}_{2}$ have numerous foci and those pretreated with mEN1 have only a few. $\boldsymbol{B}$, Quantification of $\gamma \mathrm{H} 2 \mathrm{AX}$ foci. $\mathrm{H}_{2} \mathrm{O}_{2}$ increases the number of foci from $\sim 1-2$ per neuron to $\sim 8$. mEN1, mOTX2, hGBX2, and hLHX9 reduce the number of foci in a dose-dependent manner. $\boldsymbol{C}, \boldsymbol{D}$, Inhibition of reverse transcriptase activity protects against $\mathrm{H}_{2} \mathrm{O}_{2}$ oxidative stress in midbrain $(\boldsymbol{C})$ and striatal neurons $(\boldsymbol{D})$. In the control condition, few $\gamma \mathrm{H} 2 \mathrm{AX}$ foci are observed in embryonic midbrain neurons, while those challenged with $100 \mu \mathrm{M} \mathrm{H}_{2} \mathrm{O}_{2}$ show multiple DNA damaged foci. Pretreatment with $10 \mu \mathrm{m}$ stavudine or $2.5 \mathrm{nM}$ hEn1 completely blocks the formation of DNA damage foci. $* * * * p<0.0001$. 

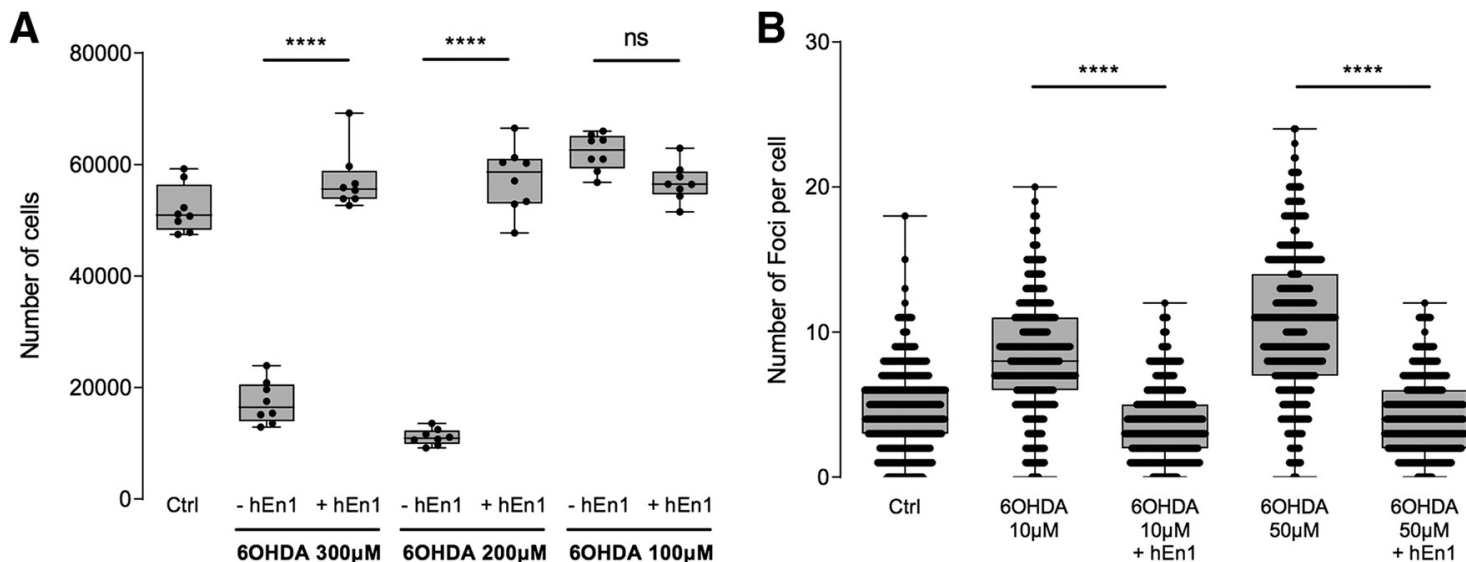

Figure 4. hEN1 protects immortalized human dopaminergic neuronal precursors, LUHMES cells, against $\mathrm{H}_{2} \mathrm{O}_{2}$ oxidative stress by $\mathrm{LDH}$ assay. $\boldsymbol{A}$, Three hundred and $200 \mu \mathrm{m}$ 6-OHDA reduce the number of LUHMES cells surviving, while $50 \mathrm{~nm}$ hEN1 completely protects against this oxidative stress. B, Quantification of $\gamma \mathrm{H} 2 \mathrm{AX}$ foci. 6-OHDA increases the number of foci by twofold to fourfold. Preincubation with hEN1 reduces the number of foci to the control level. ns, nonsignificant, $* * * * p<0.0001$

of their protective activity that parallels their structure conservation (Banerjee-Basu and Baxevanis, 2001; Holland and Takahashi, 2005; Holland, 2013). The HPs tested here were all effective on neurons originating from the mesencephalon and telencephalon, two structures of different ontogenetic origins, thus expressing different repertoires of developmental genes. ENGRAILED and OTX2 expressed in the midbrain provide protection to striatal neurons and, conversely, GBX2 and LHX9 that are expressed in striatum are effective in providing protection to ventral midbrain neurons. These results raise the possibility that neuroprotective activity may be common to HPs in a non-region-specific manner. Interestingly, cellpermeant MYC, a transcription factor of the basic helixloop-helix family with major roles in cell cycle progression, apoptosis, and cellular transformation, showed no neuroprotective effect against oxidative stress induced by $\mathrm{H}_{2} \mathrm{O}_{2}$.

In contrast with their neuroprotective activity for terminally differentiated nonproliferating embryonic neurons, astrocytes, and the LUHMES immortalized human dopaminergic neuronal precursor cell line, none of the HPs tested was able to protect HeLa cells, primary macrophages, or primary fibroblasts from $\mathrm{H}_{2} \mathrm{O}_{2}$ oxidative stress. Because all tests on non-neural cells were performed in the presence of the Ara $\mathrm{C}$ mitotic inhibitor and because the LUHMES cells are protected by hEN1, it is unlikely that the absence of protection in non-neural cells is due only to their proliferative status. A possible explanation, based on the importance of hEN1 in mDA neurons in chromatin remodeling (Rekaik et al., 2015) is that the chromatin structure of the proliferative cells tested here is sensitive to HP expression. Alternatively, but not mutually exclusive, cofactors required of HP protection might not be available in these non-neural cells. Finally, oxidative stress increases LINE-1 expression and retrotransposition events, increasing DNA damage. ENGRAILED reduces dopaminergic neurodegeneration by repressing LINE-1 expression in vivo (Blaudin de Thé et al., 2018). The results here extend the protective effects of the reverse transcriptase inhibitor stavudine to embryonic midbrain cells and striatal cells in vitro.

All in all, our results show that EN1, EN2, OTX2, GBX2, and LHX9 representing three different classes of HP transcription factors can protect embryonic cultured neurons from two ontogenetically diverse brain regions against $\mathrm{H}_{2} \mathrm{O}_{2}$-induced oxidative stress. The similar neuroprotection by ENGRAILED proteins from different species (i.e., chicken, mouse, and human) demonstrates a strong evolutionary conservation of this activity. The ENGRAILED genes of vertebrates and insects arose as independent duplication of an ancestral ENGRAILED gene (Dolecki and Humphreys, 1988), and this duplication occurred after the divergence of echinoderms and vertebrates but before the divergence leading to birds and mammals some 310 million years ago (Logan and Joyner, 1989; Benton, 1993; Kumar and Hedges, 1998). This suggests that ENGRAILED neuroprotective activity arose before the separation between birds and mammals. More strikingly, HPs can compensate between classes as shown by the fact that OTX2 of the PRD class is able to compensate for EN1-dependent neuronal loss in vivo, although ENGRAILED belongs to the ANTP-class (Di Giovannantonio et al., 2013). Thus, neuroprotective activity arose before the divergence of ANTENNAPEDIA and PAIRED classes of HPs. The early emergence of HP protection and the selective pressure to maintain it over hundreds of millions of years underscores the importance of this HP activity.

\section{References}

Aida Y, Pabst MJ (1990) Removal of endotoxin from protein solutions by phase separation using Triton X-114. J Immunol Methods 132:191-195.

Alvarez-Fischer D, Fuchs J, Castagner F, Stettler O, MassianiBeaudoin O, Moya KL, Bouillot C, Oertel WH, Lombès A, Faigle W, Joshi RL, Hartman A, Prochiantz A (2011) Engrailed protects mouse midbrain dopaminergic neurons against mitochondrial complex I insults. Nat Neurosci 14:1260-1266.

Banerjee-Basu S, Baxevanis AD (2001) Molecular evolution of the homeodomain family of transcription factors. Nucleic Acids Res 29:3258-3269. 
Blaudin de Thé FXB, Rekaik H, Peze-Heidsieck E, MassianiBeaudoin O, Joshi RL, Fuchs J, Prochiantz A (2018) Engrailed homeoprotein blocks degeneration in adult dopaminergic neurons through LINE-1 repression. EMBO J 37:e97374.

Benton MJ, ed (1993) The fossil record 2 (No. 561/569 FOS). Amsterdam: Springer Netherlands.

Boncinelli E (1997) Homeobox genes and disease. Curr Opin Genet Dev 7:331-337.

Brunet I, Weinl C, Piper M, Trembleau A, Volovitch M, Harris W, Prochiantz A, Holt C (2005) The transcription factor Engrailed-2 guides retinal axons. Nature 438:94-98.

Bunch H, Lawney BP, Lin YF, Asaithamby A, Murshid A, Wang YE, Chen BP, Calderwood SK (2015) Transcriptional elongation requires DNA break-induced signalling. Nat Commun 6:10191.

Derossi D, Joliot AH, Chassaing G, Prochiantz A (1994) The third helix of the Antennapedia homeodomain translocates through biological membranes. J Biol Chem 269:10444-10450.

Derossi D, Calvet S, Trembleau A, Brunissen A, Chassaing G, Prochiantz A (1996) Cell internalization of the third helix of the Antennapedia homeodomain is receptor-independent. J Biol Chem 271: 18188-18193.

Di Giovannantonio LG, Di Salvio M, Acampora D, Prakash N, Wurst W, Simeone A (2013) Otx2 selectively controls the neurogenesis of specific neuronal subtypes of the ventral tegmental area and compensates En1-dependent neuronal loss and MPTP vulnerability. Dev Biol 373:176-183.

Di Nardo AA, Nedelec S, Trembleau A, Volovitch M, Prochiantz A, Montesinos ML (2007) Dendritic localization and activitydependent translation of Engrailed1 transcription factor. Mol Cell Neurosci 35:230-236.

Di Nardo AA, Fuchs J, Joshi RL, Moya KL, Prochiantz A (2018) The physiology of homeoprotein transduction. Physiol Rev 98:19431982.

Dolecki GJ, Humphreys T (1988) An engrailed class homeo box gene in sea urchins. Gene 64:21-31.

Holland PW (2013) Evolution of homeobox genes. Wiley Interdiscip Rev Dev Biol 2:31-45.

Holland PW, Takahashi T (2005) The evolution of homeobox genes: implications for the study of brain development. Brain Res Bull 66:484-490.

Joliot A, Maizel A, Rosenberg D, Trembleau A, Dupas S, Volovitch M, Prochiantz A (1998) Identification of a signal sequence necessary for the unconventional secretion of Engrailed homeoprotein. Curr Biol 8:856-863.

Jozefczuk J, Drews K, Adjaye J (2012) Preparation of mouse embryonic fibroblast cells suitable for culturing human embryonic and induced pluripotent stem cells. J Vis Exp. Advance online publication. Retrieved June 6, 2012. doi: 10.3791/3854.

Kumar S, Hedges SB (1998) A molecular timescale for vertebrate evolution. Nature 392:917.

Le Roux I, Joliot AH, Bloch-Gallego E, Prochiantz A, Volovitch M (1993) Neurotrophic activity of the Antennapedia homeodomain depends on its specific DNA-binding properties. Proc Natl Acad Sci U S A 90:9120-9124.

Logan C, Joyner AL (1989) An Haelll RFLP for the human homeo box-containing gene EN1. Nucleic Acids Res 17:2877.

Moravec R (1994) Total cell quantitation using the CytoTox $96 \AA$ non-radioactive cytotoxicity assay. Promega Notes 45:11-12.

Rekaik H, de Thé FXB, Fuchs J, Massiani-Beaudoin O, Prochiantz A, Joshi RL (2015) Engrailed homeoprotein protects mesencephalic dopaminergic neurons from oxidative stress. Cell Rep 13:242-250.

Rubin E, Wu X, Zhu T, Cheung JC, Chen H, Lorincz A, Pandita RK, Sharma GG, Ha CH, Gasson J, Hanakahi LA, Sukumar S (2007) A role for the HOXB7 homeodomain protein in DNA repair. Cancer Res 67:1527-1535.

Sonnier L, Le Pen G, Hartmann A, Bizot JC, Trovero F, Krebs MO, Prochiantz A (2007) Progressive loss of dopaminergic neurons in the ventral midbrain of adult mice heterozygote for Engrailed1. J Neurosci 27:1063-1071.

Stettler O, Joshi RL, Wizenmann A, Reingruber J, Holcman D, Bouillot C, Castagner F, Prochiantz A, Moya KL (2012) Engrailed homeoprotein recruits the adenosine $\mathrm{A} 1$ receptor to potentiate ephrin A5 function in retinal growth cones. Development 139: 215-224.

Thomasson N, Pioli E, Friedel C, Monseur A, Lavaur J, Moya KL, Bezard E, Bousseau A, Prochiantz A (2019) Engrailed-1 induces long-lasting behavior benefit in an experimental Parkinson primate model. Mov Disord 34:1082-1084.

Torero-lbad RT, Rheey J, Mrejen S, Forster V, Picaud S, Prochiantz A, Moya KL (2011) Otx2 promotes the survival of damaged adult retinal ganglion cells and protects against excitotoxic loss of visual acuity in vivo. J Neurosci 31:5495-5503. 